\title{
Factors influencing utilisation of family planning services among female of reproductive age (15-45 years) in Bauchi local government area, Bauchi state
}

\author{
Ekpenyong $\mathrm{MS}^{1 *}$, Nzute $\mathrm{AI}^{1}$, Odejimi $\mathrm{O}^{1}$ and Abdullahi $\mathrm{AD}^{2}$ \\ ${ }^{1}$ Faculty of Education, Health and Wellbeing, University of Wolverhampton, UK \\ ${ }^{2}$ Umar Suleiman College of Education Gashu'a, Yobe State, Nigeria
}

\begin{abstract}
Background: Family Planning services are preventive health services that provide quality, low cost and easily accessible reproductive health care to women and men during their reproductive years. Family planning is often limited to the use of contraception. However, family planning provides a holistic service that aims to promote a positive view of sexuality and enable people to make informed choices about their sexual and reproductive health and well-being. It also ensures that resources are available for raising a child in significant amount, which include time, finance and social environment at intervals mutually determined by both partners to have their desired number of children. Studies indicates that the utilisation of family planning services in Nigeria is low when compared to high population growth rate in Africa, high fertility that translates into high population growth. Many scholars reported that it is likely that the utilisation of family planning services can alter the population growth rate. Studies have also shown that contraceptive knowledge, and usage is very low in Nigeria, hence the reason for the high fertility and increase population.
\end{abstract}

Aim: There for the study aimed at determining factors influencing the utilisation of family planning services among female of reproductive age (15-45 years) in Bauchi Local Government Area, Bauchi State, Nigeria.

Method: A descriptive cross-sectional study was conducted. Hundred questionnaires were distributed to 100 women of reproductive age of which 96 of them were retrieved. Data was analysed using Statistical Package for Social Sciences (SPSS). Descriptive statistics was used to summarise and organise the data. Pearson's Chisquare test was used to test for association between variables and level of significant was set at 5\% (0.05).

Findings: Results from this study show that (84.4\%) respondent's utilisation of family planning services depends on husband's acceptance of the family planning method. The study also found that cultural acceptance, access to family planning services, schedule of family planning clinic, effectiveness of family planning method and awareness; $75 \%, 75 \%, 62.5 \%, 79.2 \%$ and $63.5 \%$ respectively all influence utilisation of family planning. Academic attainment and knowledge of family planning methods were significant and influence family planning use.

Conclusion: The study showed that family planning used depends on husband's acceptance of the family planning method. This study also recommends for spouses to be continuously involved in family planning education as their approval influences family planning. It is hoped that the knowledge of this research will help health care givers to provide adequate health education to clients and family in the community to expand their knowledge of family planning services to ensure adequate child spacing and reproductive health. Thus, preventing unintended pregnancies, reduce maternal and child morbidity and mortality rate.

\section{Introduction}

Family planning services is an educational, comprehensive medical or social activity which enables individuals to determine freely the number and spacing of their children and to select how this may be achieved [1]. The National Survey of Family Growth (NSFG) in Chandra, et al. [2] indicated that $41.7 \%$ of women of reproductive age receive at least one family planning service from a medical care provider either already pregnant, seeking to become pregnant or infertile because of sterilization.

Nonetheless, the low percentage of individuals using family planning services suggests that either some women are not planning their pregnancies deliberately or they are experiencing problems accessing this type of services [3]. Family planning in Nigeria is one of the pillars of safe motherhood where women can access services that would prevent unwanted pregnancies [4]. In Nigeria, family planning services are frequently delivered in clinics with little or no connection with medical facilities. The utilisation of these services in Nigeria is low when compared to the high fertility and population growth rate in Africa, high fertility translates into high population, and the growth rate was estimated to be between 2.5 and 3.0 per cent per annum $[5,6]$. Osemwenkha [6] further stated that it is likely that the utilisation of family planning services can alter the population growth rate, reports have shown that contraceptive knowledge, and usage is very low in Nigeria, hence the reason for the high fertility and increased population.

*Correspondence to: Ekpenyong MS, Faculty of Education, Health and Wellbeing, University of Wolverhampton, UK, E-mail: ladyekpenyong@gmail.com; opeyemi. odejimi@gmail.com

Key words: family planning, utilisation, women of reproductive age

Received: February 14, 2018; Accepted: March 19, 2018; Published: March 22, 2018 
The underutilisation of family planning methods in these regions is attributed to low literacy and low socio-economic status of women [7]; and spousal communication on family planning has also been found to influence contraception use [8]. Again, a study by Chacko [9] found that the number of living sons a woman has also influences her contraceptive use. The resultant effect of underutilisation of these services is a leading cause to the high prevalence of teenage pregnancy and maternal deaths in Africa.

According to Cleland, et al. [1] family planning services are necessary for the widespread of adoption of preconception care for planning pregnancies and counseling. The potential of family planning services is to promote preconception care which is limited by underutilisation of these services and adequate attention to preconception care during the reproductive years is dependent on the woman and man planning their pregnancies, not only in respect to their timing but also on health-related factors that would maximize their chances for a healthy pregnancy and healthy infant.

Child spacing, which is one of the benefit of utilising family planning services have been identified as a means of reducing maternal deaths [10]. Globally, 99\% of maternal deaths and disability occur in the developing countries, and Nigeria alone accounts for 10 percent [11]. In addition, utilisation of family planning helps to prevent women from participating in unsafe abortion practices [4]. This is because in Nigeria, like many other African countries, abortion is illegal and the United Nation Population Fund (UNFPA) 2009 reported that 74,000 women were estimated to die because of unsafe abortion. This report further explains that 50 million induced abortions were performed each year of which 20 million are performed in unsafe conditions or by untrained providers. Thus, the use of family planning services reduces the number of unintended pregnancies, thereby promoting women reproductive health by decreasing the number of times a woman is exposed to the risk of pregnancy and child bearing in adverse conditions [12]. Family planning saves lives and can improve the health of women, children and society as a whole

The National Survey of Family Growth (NSFG) (2002) reported that $41.7 \%$ of women 15 to 44 years of age received at least one family planning service from a medical care provider. This percentage is not as alarming as it might appear at first glance, because some of the women who did not seek family planning services already were pregnant, seeking to become pregnant, or infertile because of sterilization or other reasons. Nevertheless, this rather low percentage suggests that some women are not either planning their pregnancies deliberately or because they are experiencing problems, obtaining family planning services [3]. The growth rate in Nigeria is estimated to be between 2.5-3.0\% increasing per annum currently estimated to 190 million persons and is expected to reach 338 million persons by 2050 , which pose various problems for economic growth and development in the country [13].

Utilisation of family planning services need to be increased and the content of such services expand to achieve the reproductive health of women. Hence, it becomes expedient to conduct this research to understanding the factors influencing utilisation of family planning services is critical to the efforts of programmes targeted at meeting the demand for contraception.

\section{Methodology}

A descriptive cross-sectional design was used for this research. It was designed to determine factors influencing the use of family planning services among females of reproductive age (15-45 years) in Bauchi Local Government Area of Bauchi State, Nigeria.

The research was carried out among women of reproductive age (15 - 45 years) in Bauchi Local Government Area, Nigeria. Bauchi is a small community with a total population of 4,676,465 people and over 104,884 females [14]. Dan'lya, Birishi and Dan'amar wards were selected within Bauchi. These wards are deprived wards and have 35,879 females of childbearing age [14].

A sample population of 100 female of reproductive age (15-45 years) was drawn out of the target population. A convenience sample was used in selecting participants who meet the study criteria. Eligible participants were female of reproductive age (15-45 years) who were willing to participate in the study.

Data was collected using semi-structured questionnaire after an extensive literature review on family planning services.

The design and conduct of this study was fully approved and monitored in accordance by the Community Heads of Dan'lya, Birishi and Dan'amar wards. Informed consent from the respondents was obtained. The working practices and confidentiality requirements of all participating individuals was fully respected and the anonymity of all participants in the research was assured.

\section{Data analysis}

Data collected was imputed into the computer using Statistical Package for Social Science (SPSS) for data analysis and results presented using descriptive statistical tools such as percentage tables. Pearson's Chisquare test was utilised. The level of significant was taken at 0.05 . Crosstabulation tables were used to explain the relationship between factors influencing utilisation of family planning and its associated variables

\section{Results}

The result was presented in five tables. Table 1 presents descriptive analysis of the socio-demographic information of study participants. Majority (41\%) of the participants were within 25-34yrs of age whilst (7\%) of the participants were within 45-54 years. Islam is the religion (84\%) practiced by most of the participants. The ethnicity of the participants was diverse with Hausa being the ethnic group with the highest proportion (26\%).

Participants were mainly educated to tertiary level (58\%) with only one participant having no form of education. Half of the participants were students (50\%) while others were either civil servants or artisan. Only a few percentage were unemployed full-time housewives (12\%). Majority of the participants earned less than 10,000 (35\%) and there were mostly single unmarried females (57.3\%). Amongst the respondents that were married (38.5\%), majority had been married for 6-10 years $(43.9 \%)$.

Most of the participants had no child (56.2\%). The result of this study reveals that $(43.7 \%)$ of women had at least one child and 2 years was the highest minimal interval (16.7\%) most of the participants space childbirth.

Table 2 illustrates the frequency distribution of participants' knowledge of family planning methods. Nearly all participants (99\%) had heard about family planning services and knowledgeable about methods of contraception. Only $1 \%$ had no prior knowledge of family planning. More participants (48.4\%) knew all methods of contraception and first learnt about family planning methods in the hospital (35.8\%). 
Ekpenyong MS (2018) Factors influencing utilisation of family planning services among female of reproductive age (15-45 years) in Bauchi local government area, Bauchi state

Majority of the participants $(62.5 \%)$ were aware that familyplanning methods does not decrease sexual urge. They (58.9\%) also agreed that it prevents Sexually Transmitted Infection (STI). More participants $(41.5 \%)$ were aware of the services rendered in a typical family planning service. Hormonal pills (66.3\%) were the most common contraceptive method used by the participants and the women mostly obtain these hormonal pills from the primary health center (56.5\%).

Table 3 shows distribution of the utilisation of family planning methods. About three-quarter of the participants (74\%) were sexually active at the time of this study, of which more participants (53.1\%) have never used any family planning methods. Amongst the participants who had used a family planning method (46.9\%), less than half of them $(47.9 \%)$ were currently using a type of family planning method. Hormonal methods (30.4\%) were the most commonly used. Fewer participants $(6.7 \%)$ visited the family planning services regularly and more participants (69.8\%) appear not to have time for follow up visits.

Table 1. Distribution of socio-demographic characteristics of respondents ( $\mathrm{n}=96)$

\begin{tabular}{|c|c|c|c|}
\hline \multicolumn{2}{|l|}{ Characteristics } & \multirow{2}{*}{\begin{tabular}{|l} 
Frequency \\
35 \\
\end{tabular}} & \multirow{2}{*}{\begin{tabular}{|l} 
Percentage (\%) \\
36.5
\end{tabular}} \\
\hline \multirow{4}{*}{ Age range } & 15-24years & & \\
\hline & 25-34years & 39 & 40.6 \\
\hline & 35-44years & 15 & 15.6 \\
\hline & 45-54years & 7 & 7.3 \\
\hline \multirow{4}{*}{ Religion } & Islam & 80 & 83.3 \\
\hline & Christianity & 12 & 12.5 \\
\hline & Traditionalist & 3 & 3.1 \\
\hline & Others specify & 1 & 1.0 \\
\hline \multirow{6}{*}{ Ethnicity } & Fulani & 24 & 25.0 \\
\hline & Igbo & 5 & 5.2 \\
\hline & Hausa & 25 & 26.0 \\
\hline & Jarawa & 15 & 15.6 \\
\hline & Yoruba & 5 & 5.2 \\
\hline & Others & 22 & 22.9 \\
\hline \multirow{4}{*}{$\begin{array}{l}\text { Academic } \\
\text { attainment }\end{array}$} & Primary education & 10 & 10.4 \\
\hline & Secondary education & 28 & 29.2 \\
\hline & Tertiary education & 57 & 59.4 \\
\hline & No education & 1 & 1.0 \\
\hline \multirow{4}{*}{ Occupation } & Civil servant & 15 & 15.6 \\
\hline & Artisan & 21 & 21.9 \\
\hline & Full-house wife & 12 & 12.5 \\
\hline & Student & 48 & 50.0 \\
\hline \multirow{4}{*}{$\begin{array}{l}\text { Average income per } \\
\text { month }\end{array}$} & Below $-10,000$ & 33 & 34.4 \\
\hline & $10,000-24,000$ & 29 & 30.2 \\
\hline & $25,000-40,000$ & 14 & 14.6 \\
\hline & Above $-40,000$ & 20 & 20.8 \\
\hline \multirow{4}{*}{ Marital status } & Single & 55 & 57.3 \\
\hline & Married & 37 & 38.5 \\
\hline & Divorced & 1 & 1.0 \\
\hline & Widow & 3 & 3.1 \\
\hline \multirow{4}{*}{$\begin{array}{l}\text { If married, for how } \\
\text { long }\end{array}$} & $1-5$ years & 15 & 36.6 \\
\hline & 6-10 years & 22 & 43.9 \\
\hline & $11-15$ years & 3 & 7.3 \\
\hline & $16-20$ years & 5 & 12.2 \\
\hline \multirow{4}{*}{ Number of children } & None & 54 & 56.2 \\
\hline & 1-2 children & 22 & 22.9 \\
\hline & 3-4 children & 13 & 13.5 \\
\hline & 5-above & 7 & 7.3 \\
\hline \multirow{5}{*}{$\begin{array}{l}\text { Minimal interval } \\
\text { between children }\end{array}$} & Months & 1 & 1.0 \\
\hline & $1 \mathrm{yr}$ & 11 & 11.5 \\
\hline & $2 \mathrm{yrs}$ & 16 & 16.7 \\
\hline & $3 y r s$ & 6 & 6.2 \\
\hline & $4 \mathrm{yrs}$ & 1 & 1.0 \\
\hline
\end{tabular}

Table 2. Frequency distribution of respondent's knowledge on Family Planning ( $\mathrm{n}=96)$

\begin{tabular}{|c|c|c|c|}
\hline \multicolumn{2}{|l|}{ Characteristics } & \multirow{2}{*}{$\begin{array}{l}\text { Frequency } \\
95\end{array}$} & \multirow{2}{*}{\begin{tabular}{|l|} 
Percentage \\
$(\%)$
\end{tabular}} \\
\hline Have you heard of family & Yes & & \\
\hline planning methods? & No & 1 & 1 \\
\hline \multirow{3}{*}{$\begin{array}{l}\text { Tick the family planning } \\
\text { method you know? }\end{array}$} & 1-2 methods & 33 & 34.7 \\
\hline & 3-4 methods & 16 & 16.8 \\
\hline & All methods & 46 & 48.4 \\
\hline \multirow{5}{*}{$\begin{array}{l}\text { Where did you first learn } \\
\text { about family planning } \\
\text { methods? }\end{array}$} & Hospital & 34 & 35.8 \\
\hline & Mass media & 13 & 13.7 \\
\hline & Friends and family & 33 & 34.7 \\
\hline & Religious institution & 3 & 3.2 \\
\hline & Literature & 12 & 12.6 \\
\hline \multirow{2}{*}{$\begin{array}{l}\text { Does family planning } \\
\text { methods decrease sexual } \\
\text { urge? }\end{array}$} & Yes & 36 & 37.5 \\
\hline & No & 60 & 62.5 \\
\hline \multirow{2}{*}{$\begin{array}{l}\text { Do some of the methods } \\
\text { prevent STI? }\end{array}$} & Yes & 56 & 58.9 \\
\hline & No & 39 & 41.5 \\
\hline \multirow{2}{*}{$\begin{array}{l}\text { Do you know the type of } \\
\text { services rendered in family } \\
\text { planning clinics? }\end{array}$} & Yes & 39 & 41.5 \\
\hline & No & 55 & 58.5 \\
\hline \multirow{13}{*}{$\begin{array}{l}\text { If yes, please list the type of } \\
\text { services to known to you? }\end{array}$} & Pregnancy test and counseling & 2 & 5.4 \\
\hline & $\begin{array}{l}\text { Pregnancy test and health } \\
\text { education }\end{array}$ & 4 & 10.8 \\
\hline & $\begin{array}{l}\text { Pregnancy test and family } \\
\text { planning }\end{array}$ & 3 & 8.1 \\
\hline & $\begin{array}{l}\text { Counseling and health } \\
\text { education }\end{array}$ & 3 & 8.1 \\
\hline & $\begin{array}{l}\text { Counseling and family } \\
\text { planning }\end{array}$ & 4 & 10.4 \\
\hline & $\begin{array}{l}\text { Family planning and health } \\
\text { education }\end{array}$ & 6 & 16.2 \\
\hline & Family planning and STI's & 2 & 5.4 \\
\hline & Health education and STI's & 1 & 2.7 \\
\hline & $\begin{array}{l}\text { Health education and cervical } \\
\text { test }\end{array}$ & 1 & 2.7 \\
\hline & $\begin{array}{l}\text { Cervical test and family } \\
\text { planning }\end{array}$ & 1 & 2.7 \\
\hline & Cervical test and breast exams & 1 & 2.7 \\
\hline & Contractive use & 7 & 19.0 \\
\hline & Health education & 2 & 5.4 \\
\hline \multirow{4}{*}{$\begin{array}{l}\text { Which of the following } \\
\text { modern family planning } \\
\text { methods are available in the } \\
\text { community? }\end{array}$} & Hormonal pills & 57 & 66.3 \\
\hline & Hormonal implants & 1 & 1.2 \\
\hline & Hormonal injections & 4 & 4.7 \\
\hline & Condom & 24 & 27.9 \\
\hline \multirow{4}{*}{$\begin{array}{l}\text { Where do you obtain family } \\
\text { planning methods in the } \\
\text { community? }\end{array}$} & Primary health center & 52 & 56.5 \\
\hline & Chemist & 27 & 29.3 \\
\hline & IUTH & 6 & 6.5 \\
\hline & Other & 7 & 7.6 \\
\hline
\end{tabular}

Table 4 indicates factors reported by participants that affects utilisation of family planning services. Factors affecting family planning utilisation include; attitude of the family planning providers, availability of facilities/equipment, awareness, schedule of family planning clinic, effectiveness of the family planning method, accessibility of family planning services, cultural acceptance, religious acceptance, husband's acceptance, except language barrier were factors, which the respondents agreed, influenced the utilisation of family planning services. Husband's acceptance had the highest agreement with $84.4 \%$ while language barrier was $49.0 \%$.

Tables 5 showed that there was a significant association between academic attainment and level of knowledge on family planning methods of females of reproductive age under study and utilisation of family planning services as the $\mathrm{p}$-values $<0.05$. 
Ekpenyong MS (2018) Factors influencing utilisation of family planning services among female of reproductive age (15-45 years) in Bauchi local government area, Bauchi state

Table 3. Distribution of utilisation of family planning methods

\begin{tabular}{|c|c|c|c|}
\hline \multicolumn{2}{|l|}{ Characteristics } & \multirow{2}{*}{\begin{tabular}{|l|} 
Frequency \\
74 \\
\end{tabular}} & \multirow{2}{*}{\begin{tabular}{|l} 
Percentage (\%) \\
74.0
\end{tabular}} \\
\hline Percentage of respondents who were sexually active at the time of this & Sexually active & & \\
\hline research & Not sexually active & 26 & 26.0 \\
\hline \multirow{2}{*}{ Have you used any family planning method before } & Yes & 45 & 46.9 \\
\hline & No & 51 & 53.1 \\
\hline \multirow{2}{*}{ If yes, are you currently using any family planning methods } & Yes & 46 & 47.9 \\
\hline & No & 50 & 52.1 \\
\hline \multirow{6}{*}{ If yes, tick the method } & Hormonal method & 14 & 30.4 \\
\hline & Barrier method & 10 & 21.7 \\
\hline & Fertility awareness & 9 & 19.6 \\
\hline & Emergency contraceptive & 2 & 4.4 \\
\hline & Abstinence & 7 & 15.2 \\
\hline & Withdrawal method & 4 & 8.7 \\
\hline \multirow{4}{*}{ When last did you visit the family planning clinic? } & Within the last 1 month & 4 & 6.7 \\
\hline & Within the last 3 months & 10 & 16.7 \\
\hline & Within the last 6 months & 10 & 16.7 \\
\hline & Others (within the last six months and above) & 36 & 60 \\
\hline \multirow{2}{*}{ Do you have time for your follow up visit to family planning clinic } & Yes & 29 & 30.2 \\
\hline & No & 67 & 69.8 \\
\hline \multirow{2}{*}{ level of respondents' knowledge on family planning methods } & High & & 69.8 \\
\hline & Low & & 30.2 \\
\hline
\end{tabular}

Table 4. Factors that influence the utilisation of family planning services frequency distribution

\begin{tabular}{|c|c|c|c|}
\hline \multicolumn{2}{|l|}{ Characteristics } & \multirow{2}{*}{$\begin{array}{c}\text { Frequency } \\
58\end{array}$} & \multirow{2}{*}{$\begin{array}{c}\text { Percentage (\%) } \\
60.4\end{array}$} \\
\hline Attitude of family nlannino nrovider & Yes & & \\
\hline Atctuce or raminy praming provider & No & 38 & 39.6 \\
\hline \multirow{2}{*}{ Availability of facilities/equipment } & Yes & 73 & 76.0 \\
\hline & No & 23 & 24.0 \\
\hline \multirow{2}{*}{ Awareness } & Yes & 61 & 63.5 \\
\hline & No & 35 & 36.5 \\
\hline \multirow{2}{*}{ Language barrier } & Yes & 47 & 51.0 \\
\hline & No & 49 & 51.0 \\
\hline \multirow{2}{*}{ Schedule of family planning clinic } & Yes & 60 & 62.5 \\
\hline & No & 36 & 37.5 \\
\hline \multirow{2}{*}{ Effectiveness of family planning method } & Yes & 76 & 79.2 \\
\hline & No & 20 & 20.8 \\
\hline \multirow{2}{*}{ Accessibility of family planning services } & Yes & 72 & 75.0 \\
\hline & No & 24 & 25.0 \\
\hline \multirow{2}{*}{ Cultural acceptance } & Yes & 72 & 75.0 \\
\hline & No & 24 & 25.0 \\
\hline \multirow{2}{*}{ Religious acceptance } & Yes & 79 & 82.3 \\
\hline & No & 17 & 17.7 \\
\hline \multirow{2}{*}{ Husband's acceptance } & Yes & 81 & 84.4 \\
\hline & No & 15 & 15.6 \\
\hline
\end{tabular}

Table 5. Association between respondents socio-demographic characteristics and family planning utilization

\begin{tabular}{|c|c|c|c|c|c|c|}
\hline \multirow{2}{*}{\multicolumn{2}{|c|}{ Variables }} & \multicolumn{2}{|c|}{ Utilisation of family planning services } & \multirow{2}{*}{$\begin{array}{c}\text { Pearson chi-square } \mathrm{X}^{2} \\
\text { (P-value) }\end{array}$} & \multirow{2}{*}{ df } & \multirow{2}{*}{ Remark } \\
\hline & & \multirow{2}{*}{$\begin{array}{c}\text { Low utility } \\
15\end{array}$} & \multirow{2}{*}{$\begin{array}{c}\text { High utility } \\
21\end{array}$} & & & \\
\hline \multirow{4}{*}{ Age range } & $15-24$ years & & & \multirow{4}{*}{$6.991(0.072)$} & \multirow{4}{*}{3} & \multirow{4}{*}{ No significant association } \\
\hline & 25-34yeras & 6 & 32 & & & \\
\hline & $35-44$ years & 5 & 10 & & & \\
\hline & 45-54years & 1 & 6 & & & \\
\hline \multirow{3}{*}{ Academic attainment } & Primary education & 3 & 7 & \multirow{3}{*}{$8.711(0.013)$} & \multirow{3}{*}{2} & \multirow{3}{*}{$\begin{array}{l}\text { There is a significant } \\
\text { association }\end{array}$} \\
\hline & Secondary education & 7 & 21 & & & \\
\hline & Tertiary education & 17 & 40 & & & \\
\hline \multirow{2}{*}{$\begin{array}{c}\text { Level of knowledge } \\
\text { of family planning } \\
\text { methods }\end{array}$} & Low level & 9 & 20 & \multirow{2}{*}{$6.569(0.037)$} & \multirow{2}{*}{1} & \multirow{2}{*}{$\begin{array}{l}\text { There is a significant } \\
\text { association }\end{array}$} \\
\hline & High level & 18 & 49 & & & \\
\hline
\end{tabular}




\section{Discussion}

The results presented in Table 1 revealed that many of the females in the community were between the age ranges of 25-34 years, this indicates that most of the females were in their prime age and sexually active as shown in Table 1 , therefore, women could become unintentionally pregnant if family planning services are utilised. Majority of the respondents were Muslims showing that the area of study is predominate by Islam with Hausa being the highest ethic group in the community. Without restrain family planning services can be utilised by anyone living in the community. According to the field survey, academic attainment of the respondents was mostly of tertiary level of education with only one respondent having no formal education exposure. Due to the establishment of secondary schools and federal university in the community, half of the respondents were students, corresponding to the high number of single females with a few as fulltime housewives having an average income of $10,000-24,000$ naira per month. Forty-two percent of the respondents had children comprising of single, married, divorced or widowed females with 16 who had more than one child having a minimal age interval between each child at 2 years, which is adequate age interval for exclusive breastfeeding, and recuperation of a mother for another pregnancy [15]. A woman's ability to space and limit her pregnancies has a direct impact on her health and well-being as well as on the outcome of each pregnancy [15]. Available statistics show Nigerians as having the second highest number of maternal deaths in the world with 59,000 deaths a year, yet child spacing is a veritable strategy to halt maternal deaths and even the incidence of unwanted pregnancies and unsafe abortions in the country [4].

Table 2 showed that most of the respondents knew the family planning services available in the community, which are taught in the family planning clinics for the benefits of females who are sexually active and want to prevent unwanted pregnancies and for couples who wished to space the births of their children. The family planning services available in the community are inclusive of counseling on the provision of family planning methods, breast examinations, cervical screening, pregnancy test, health education on sexually transmitted infections (STF's) amongst other private issues that are personal to the client provided by the family planning clinic staff.

Table 3 indicated that majority of the respondents were aware of the available methods of family planning in the community mostly from friends and family while the least was from the mass media. Condom, hormonal pills and injections are readily available family planning methods in the community, as condoms and hormonal pills can be easily purchased over the counter without a doctor's prescription and the individual does not require the assistance of trained personnel to administer the medications or use the condom compare to the use of hormonal injections or other methods of family planning.

The total number of condoms provided by international donors has been relatively low. Between 2000 and 2005, the average number of condoms distributed in Nigeria by donors was 5.9 per man, per year, and in 2002, 75 per cent of health services facilities visited in a survey did not have any condom or contraceptive supplies [13], this in turn does not encourage the utilisation of family planning services due to lack of needed contraceptive methods.

All these factors listed in Table 4 apparently influence the utilisation of family planning services by females of reproductive age in the community, as the attitude of the family planning providers will enable a good communication between the provider and the consumer.
The availability of facilities/equipment will ensure adequate care to be provided to the consumer at every visit. Lack of awareness prevents adequate use of the services even though the services are available to the community, language barriers alters communication leading to inappropriate transfer of information. Further, schedule of family planning clinic enables for proper planning of visit, effectiveness of family planning methods, and further confidence for utilisation, accessibility of family planning services being use and the cultural, religious and husband's acceptance boosts utilisation of family planning services. Educational attainment and level of knowledge about family planning methods were statistical significant to family use. The findings of the current study echoed in many other studies. Oyedokun [7] found that well educated women are more willing to engage in innovative behaviour than less educated women and in many developing countries, the use of family planning methods remains innovative; Koc [16] also reported a positive association between educational level of both women and their spouses and use of contraceptive methods.

\section{Conclusion}

As identified from the study, female of reproductive age utilised family planning methods that are available in their community, which is inclusive of condom, hormonal pills and hormonal injections found in the primary health care centers' and in the patent medicine store that serve the community. Family planning services help men and women of childbearing age make informed decisions about their reproductive health. The benefits of family planning extend well beyond the individual seeking advice or treatment. Access to these services empowers people to make appropriate choices for their lifestyle and have a positive impact on society. Women who can plan the number and timing of the birth of their children enjoy improved health, experience fewer unplanned pregnancies and births, and are less likely to have an abortion and its resultant complication.

Access to family planning services is vital to the health and future of females leading to safe motherhood. The ability to plan the number and spacing of births increases the likelihood for positive health outcomes for women, men, and their children. Improving knowledge about contraception and ensuring access to effective family planning options for residents in need are essential to decreasing unintended pregnancies and increasing intended pregnancies.

Changes in attitudes towards contraception among Nigerians will increase their practice of contraception and improve their reproductive health.

The knowledge of this research will help healthcare givers to provide adequate health education to clients and family in the community to expand their knowledge of family planning services to ensure adequate child spacing and reproductive health.

In addition, nurses and midwives will be able to provide adequate health information to people in the community on the benefits of child spacing through the family planning methods to enhance their utilisation and prevent unintended pregnancy and abortions.

\section{Recommendations}

Based on the findings of this study the following recommendations were made; Family planning services should be made available, accessible and affordable to high-risk groups. Counseling should be done in religious institution to propagate the knowledge of family planning and encourage the utilisation of the services by their members to enhance their reproductive health. Men plays an active part in their 
family's decision making, therefore health care provider should educate men on benefit of family planning services to enhance its acceptance and utilisation among women of reproductive age. Lastly, the public should be enlightened on family planning services through the mass media, as it is the largest means of dissemination of information.

\section{Reference}

1. Cleland J, Bernstein S, Ezeh A, Faundes A, Glasier A, et al. (2006) Family planning: the unfinished agenda. Lancet 368: 1810-1827. [Crossref]

2. Chandra A, Martinez GM, Mosher WD, Abma JC, Jones J (2005) Fertility, family planning, and reproductive health of US women: data from the 2002 National Surveyo Family Growth. Vital and health statistics. Series 23, Data from the National Survey of Family Growth, (25), pp: 1-160.

3. Klerman LV (2006) Family planning services: an essential component of preconception care. Matern Child Health J 10: 157-160.

4. Godwin H (2009) Nigeria: Family Planning basis for Safe Motherhood. This Day newspaper (7th, September 2009).

5. Odimegwu CO (1999) Family planning attitudes and use in Nigeria: a factor analysis. International Family Planning Perspectives, pp: 86-91.

6. OsayiOsemwenkha S (2004) Gender issues in contraceptive use among educated women in Edo state, Nigeria. Afr Health Sci 4: 40-49. [Crossref]
7. Oyedokun AO (2007) Determinants of contraceptive usage: lessons from women in Osun State, Nigeria. Journal of Humanities and Social Science 1: 1-14.

8. Narary PK (2001) An investigation into contraceptive use in Assam, Mumbai, India. International Institute for Population Sciences.

9. Chacko E (2001) Women's use of contraception in rural India: a village-level study. Health Place 7: 197-208. [Crossref]

10. Campbell OM, Graham WJ, Lancet Maternal Survival Series steering group (2006) Strategies for reducing maternal mortality: getting on with what works. The Lancet 368: $1284-1299$.

11. Ekpenyong MS, Ekpenyong AS (2011) Socio-Medical Analysis of Morbidity Pattern and Pregnancy Outcome of Mothers at Adeojo Maternity Hospital, Ibadan, Oyo State, South-West Nigeria. Global Education Journal.

12. World Population Department (1996) For economic and social information and Policy Analysis, Population Division. New York.

13. UNFPA (2005) Donor support for contraceptives and condoms for STI/HIV prevention 2005. http://www.unfpa.org/publicatio/detail.cfm?ID=325. Accessed July 14th, 2016.

14. National population Commission (2006) National Population Census. Abuja, Nigeria: National Population Commission.

15. World Health Organization (2010) The optimal duration of exclusive breastfeeding Available at: www.who.int/inf-pr-2001/er/note2010-07.html. Accessed August 17th 2016

16. Koc I (2000) Determinants of contraceptive use and method choice in Turkey. J Biosoc Sci 32: 329-342. [Crossref]

Copyright: ${ }^{2} 2018$ Ekpenyong MS. This is an open-access article distributed under the terms of the Creative Commons Attribution License, which permits unrestricted use, distribution, and reproduction in any medium, provided the original author and source are credited. 